Jurnal Ilmu Hukum

FAKULTAS HUKUM UMSU

\title{
PENDIDIKAN ANTI KEKERASAN BAGI MASYARAKAT GUNA PENCEGAHAN PERILAKU KEKERASAN PADA ANAK
}

\author{
Nursariani Simatupang, Rachmad Abduh
}

Fakultas Hukum Universitas Muhammadiyah Sumatera Utara

Jl. Kapten Mukhtar Basri No. 3, Medan-Sumatera Utara, Indonesia

Telp: (061) 6622400, Fax: (061) 6623474, 6631003), Kode Pos 20238

Email: nursarianisimatupang@umsu.ac.id, rachmadabduh@umsu.ac.id

\begin{abstract}
Abstrak
Kekerasan pada anak kerap terjadi, salah satu penyebab perilaku kekerasan pada anak adalah kebiasaan melakukan kekerasan oleh orang yang lebih dewasa yang seolah-olah sudah menjadi sebuah kebiasaan dan layak untuk dilakukan. Perilaku kekerasan sangat berkontribusi kepada tindakan kejahatan yang sangat merugikan. Permasalahan yang dihadapi adalah masyarakat belum memahami sepenuhnya tentang perilaku kekerasan pada anak serta dampaknya, pentingnya melakukan upaya pencegahan perilaku kekerasan pada anak, dan kurangnya kemampuan masyarakat dalam memecahkan masalah yang berkaitan dengan pencegahan perilaku kekerasan pada anak. Berdasarkan data hasil monitoring dan evaluasi yang telah dilakukan oleh tim pelaksana terhadap program PKM dapat diambil beberapa kesimpulan diantaranya, yaitu; bahwa program PKM sangat bermanfaat bagi warga masyarakat, dimana program PKM yang telah dilaksanakan bisa berjalan dengan baik tanpa ada hambatan yang berarti terlihat masyarakat sangat antusias mengikuti kegiatan yang dilaksanakan dan masyarakat dapat melakukan pemecahan masalah jika terjadi perilaku kekerasan pada anak.
\end{abstract}

\section{Kata Kunci: Pendidikan, Anti, Kekerasan, Masyarakat, Anak.}

\section{Abstract}

Violence in children often occurs. One of the causes of violent behavior in children is the habit of committing violence by older people who seems to have become a habit and deserves to do. This gives rise to imitation by children, because children are accomplished imitators. They begin to abuse other children, without knowing the impact on their future. Violent behavior greatly contributes to a very harmful crime. The problem faced is that the community does not fully understand the behavior of violence on children and its impact, the importance of making efforts to prevent violent behavior on children, and the lack of community's ability to solve problems related to the prevention of violent behavior on children. This research is a type of normative juridical research. The output that will be generated is in the form of anti-violence education counseling for community members to prevent violence in children. The target audience of the program are 100 members of the Medan Marelan 600 Community Youth Association and 100 members of the Karang Taruna Karya Buana Medan. This activity was filled with the provision of material relating to violent behavior towards children and its effects, prevention of violent behavior on children and providing legal training for the community through the provision of related cases to resolve the problem. After that continued with discussion.

Keywords: Education, Anti, Violence, Society, Children. 
DE IEGA LATA

Jurnal Ilmu Hukum

FAKULTAS HUKUM UMSU
Pendidikan Anti Kekerasan...(Nursariani, Rachmad Abduh)

Volume 5 Nomor 1, Januari - Juni 2020, 1-9

DOI: https://doi.org/10.30596/dll.v5i1.3290

\section{PENDAHULUAN}

Kekerasan terhadap anak merebak di sekitar kita. Bahkan kekerasan terhadap anak seakan-akan sudah seperti menjadi sebuah kebiasaan dalam masyarakat. Kekerasan terhadap anak dianggap sebagai sebuah perbuatan yang layak untuk dilakukan terutama ketika anak melakukan kesalahan. Ironisnya, pelaku kekerasan terhadap anak tersebut tidak hanya dilakukan oleh orang yang dewasa, tetapi kekerasan terhadap anak juga dilakukan oleh anak. Tindakan kekerasan diantaranya dilakukan secara keji berupa penyiksaan, dan ada yang berujung kepada kematian. Terkadang kekerasan terhadap anak tidak dilakukan sendirian tetapi juga secara berkelompok.

Kekerasan terhadap anak kerap terjadi, namun terkadang kita melupakan asal perilaku kekerasan itu muncul. Tanpa disadari ternyata salah satu penyebab perilaku kekerasan adalah kebiasaan yang timbul dan berkembang dalam kehidupan masyarakat sehari-hari. Kekerasan bukan saja terjadi dalam bentuk fisik namun juga dalam bentuk psikis yang mana efeknya tidak terlihat oleh kasat mata seperti halnya kekerasan fisik. (Erwin Asmadi, 2018, h. 43). Masyarakat acapkali berbuat tanpa memikirkan terlebih dahulu akibat yang timbul dari perbuatan yang dilakukannya. Perilaku masyarakat yang tidak sabar, ingin menyelesaikan masalah dengan mudah, ingin memperoleh hasil dengan cepat, tanpa ingin bersusah payah menimbulkan perilaku kekerasan yang menjurus kepada tindakan kejahatan.

Kebiasaan dalam masyarakat yang berkontribusi terhadap perilaku kekerasan yang menjurus kepada tindakan kejahatan antara lain adalah berupa;

1. Tindakan kasar yang dapat mencelakakan anak. Misalnya tindakan memukul, menendang, menampar, meninju, menjewer sampai lebam, dan menggigit.

2. Ucapan kasar yang tidak menimbulkan luka fisik, tetapi dapat menimbulkan luka psikis, seperti mengejek, menghina, memaki, dan memanggil dengan sebutan hewan.

Hal tersebut berakibat peniruan oleh masyarakat di sekitarnya, khususnya anak. Orang yang lebih dewasa kerap melupakan bahwa anak adalah sosok peniru ulung. Peniruan oleh anak saat ini banyak tersebar dari berbagai hal, baik itu dari tindakan orang dewasa yang ada di rumahnya, di lingkungan sekitarnya, lingkungan pendidikannya, dari televisi, dunia maya, gadget, game yang tersebar di internet dan tayangan-tayangan berbau kekerasan yang dapat diperoleh anak dari berbagai film yang ditontonnya.

Kekerasan terhadap anak adalah tindakan melukai yang berulang-ulang secara fisik dan emosional terhadap anak yang ketergantungan, melalui desakan hasrat, hukuman badan yang tak terkendali, degradasi dan cemoohan permanen (Abu Huraerah, 2012, h. 47). Maraknya perilaku kekerasan pada anak yang menjurus kepada tindakan kejahatan mengakibatkan keresahan dalam masyarakat yang tergabung dalam Ikatan Komunitas Pemuda Tanah 600 Medan Marelan, Medan dan Karang Taruna Karya Buana Medan. Apalagi saat ini tidak sedikit di antara anggota masyarakat bahkan generasi muda yang kerap melakukan kekerasan.

Perilaku kekerasan pada anak oleh masyarakat dianggap sebagai sebuah kebiasaan yang wajar dilakukan. Masyarakat beranggapan bahwa perbuatan tersebut bukanlah tindakan kejahatan yang dapat dipidana, karena perbuatan tersebut sudah biasa dilakukan sejak zaman nenek moyang mereka. Anggapan yang salah tentunya. Jika kebiasaan tersebut dilakukan 
DE LEGA LATA

Jurnal Ilmu Hukum

FAKULTAS HUKUM UMSU
Pendidikan Anti Kekerasan...(Nursariani, Rachmad Abduh)

Volume 5 Nomor 1, Januari - Juni 2020, 1-9

DOI: https://doi.org/10.30596/dll.v5i1.3290

dapat menimbulkan kesenjangan bahkan merusak moral bangsa serta melahirkan peniruanpeniruan bagi generasi muda selanjutnya. Perilaku kekerasan sangat berkontribusi kepada tindakan kejahatan yang sangat merugikan. Kekerasan terhadap anak merusak masa depannya yang berakibat merusak moral bangsa. Tindakan kekerasan yang dalam masyarakat dapat berakibat fatal, yaitu dapat mengakibatkan lahirnya pelaku-pelaku kekerasan berikutnya. Apalagi jika hal tersebut tidak dibarengi dengan pendidikan anti kekerasan. Hal inilah yang tidak dipahami oleh para generasi muda yang tergabung dalam Ikatan Komunitas Pemuda Tanah 600 Medan Marelan, Medan dan Karang Taruna Karya Buana Medan. Mereka khawatir dengan semakin meningkatnya angka kejahatan di Indonesia, namun di antara mereka masih terus melakukan kekerasan terhadap anak.

Beberapa tindakan kekerasan yang biasa dilakukan oleh generasi muda adalah kekerasan fisik dan kekerasan psikis (dalam beberapa hal ada yang menimbulkan luka, baik luka fisik maupun luka psikis), yaitu antara lain memukul, menendang, memijak, melempar dengan menggunakan batu, mengancam, menghina, mengejek, meludahi, dan memanggil teman dengan nama hewan.

Bahkan di antara mereka mulai mengikuti pola tingkah laku para pelaku kejahatan yaitu melakukan kejahatan tidak sendiri, tetapi dilakukan secara berkelompok, sedangkan korbannya hanya sendiri. Di sisi lain bahkan kekerasan yang mereka lakukan sudah terencana agar memperoleh hasil yang diinginkan. Ada yang melakukan kekerasan terhadap teman permainannya atau bahkan terhadap adik kelas di sekolahnya, yang dianggap bersalah, tidak disukai, atau tidak mau bersepakat dengan para pelaku. Sebagian anak-anak ada yang menjadikan temannya menjadi korban kekerasan karena korban tidak mau berbagi uang pada pelaku atau tidak mau mengerjakan pekerjaan yang dimintakan oleh pelaku. Perbuatan tersebut tidak hanya merugikan korban, tetapi juga merugikan masa depan pelaku kekerasan sebagai generasi penerus bangsa.

Kondisi yang sungguh sangat ironi. Sangat miris jika kondisi ini tidak segera dibenahi, apalagi pelakunya adalah masih berusia muda bahkan ada yang masih berusia anak (Nashriana, 2012, h. 1) tentunya. Generasi muda yang seharusnya menjadi penerus cita-cita bangsa di masa depan. Jika hal ini tidak diatasi sejak dini, tentunya dapat berakibat fatal bagi masa depan para generasi muda. Sebagai generasi muda mereka akan tumbuh menjadi pelaku kejahatan. Bahkan dapat menjadi penjahat yang lebih lihai dibandingkan para penjahat yang ada saat ini. Mereka telah terbiasa dengan perilaku-perilaku kekerasan sejak usia muda dan meniru perbuatan penjahat. Hal ini yang tidak dipahami oleh masyarakat yang tergabung dalam Ikatan Komunitas Pemuda Tanah 600 Medan Marelan, Medan dan Karang Taruna Karya Buana Medan. Masyarakat tidak memahami bahwa perilaku kekerasan pada anak dapat berkontribusi kepada tindakan kejahatan. Kekerasan dapat membuat bangsa ini menjadi bangsa yang lemah dan tidak berdaya. Mereka hanya memahami bahwa setiap hal harus dilaksanakan dengan cepat sesuai dengan keinginannya, walaupun dibarengi dengan perilaku kekerasan bahkan mengikuti cara-cara yang dilakukan penjahat melakukan tindakan kejahatan.

Kekerasan yang terjadi pada anak begitu memprihatinkan di negara kita. Oleh karena itu kekerasan terhadap anak harus diberantas melalui pencegahan sejak dini. Salah satu cara 
DE LEGA LATA

Jurnal Ilmu Hukum

FAKULTAS HUKUM UMSU
Pendidikan Anti Kekerasan...(Nursariani, Rachmad Abduh)

Volume 5 Nomor 1, Januari - Juni 2020, 1-9

DOI: https://doi.org/10.30596/dll.v5i1.3290

untuk memberantasnya adalah dengan melakukan pencegahan sejak dini bagi masyarakat khususnya para generasi muda. Salah satu upaya jangka panjang yang terbaik untuk mengatasi kekerasan pada anak adalah dengan memberikan pendidikan anti kekerasan kepada masyarakat khususnya kalangan generasi muda. Hal ini juga ditujukan agar pelaksanaan hukum dapat berhasil karena keberhasilan dalam pelaksanaan hukum itu dibuat agar tercapai maksudnya (Fajaruddin, 2018, h. 207).

Beberapa aspek yang berhubungan dengan anti kekerasan yang dirumuskan oleh UNESCO adalah; (M. Noor Rochman Hadjam dan Wahyu Widiarso, 2003, h. 14)

1. Penghargaan terhadap kehidupan

2. Anti kekerasan.

3. Berbagi dengan yang lain.

4. Mendengar untuk memahami.

5. Menjaga kelestarian bumi.

6. Solidaritas.

7. Persamaan antara lelaki dan perempuan.

8. Demokrasi.

Melalui pendidikan anti kekerasan generasi muda diberikan pemahaman dan penanaman nilai-nilai agar berperilaku anti kekerasan. Selain itu melalui pendidikan anti kekerasan masyarakat diajak untuk mengembangkan dan mengamalkan nilai-nilai anti kekerasan. Jika nilai-nilai anti kekerasan ditanamkan pada generasi muda sejak dini, maka nilai-nilai tersebut akan tertanam hingga kelak mereka dewasa dan membentuk mental anti kekerasan serta menjadikan generasi muda tumbuh menjadi anak bangsa yang berkarakter mulia.

Melalui pendidikan anti kekerasan generasi muda didorong untuk berperan serta memerangi segala tindakan kekerasan dengan sesuai dengan kapasitas dan kewenangan masing-masing. Melalui pendidikan anti kekerasan ditanamkan nilai-nilai positif dalam menghadapi masalah serta kebencian terhadap kekerasan melalui pesan-pesan moral serta menghimbau agar masyarakat ikut serta dalam menindaklanjuti (berperan aktif) dalam memberantas tindakan kekerasan yang terjadi di sekitar lingkungan mereka.

Para generasi muda harus dihindarkan dari perilaku kekerasan guna melakukan pencegahan tindakan kejahatan. Namun tidak sedikit dari masyarakat yang kurang memahami akan bahaya kekerasan dan cara pencegahannya serta upaya untuk menghindarkan dari perilaku kekerasan yang menjurus kepada perbuatan kejahatan.

Kekerasan harus dimusnahkan dengan mengerahkan kekuatan secara massif, artinya bukan hanya pemerintah saja melainkan seluruh lapisan masyarakat khususnya para generasi muda. Anak harus didorong untuk menjadi pribadi yang penuh dengan kebaikan, ketulusan, keimanan, dan ketaqwaan agar dapar menjalan perannya sebagai generasi penerus bangsa serta mampu bekerja sama dengan pihak lain tanpa mengedepankan kekerasan.

Berdasarkan analisis situasi yang telah dipaparkan di atas, masalah yang dihadapi oleh Ikatan Komunitas Pemuda Tanah 600 Medan Marelan, Medan dan Karang Taruna Karya Buana Medan adalah; 
DE LEGA LATA

Jurnal Ilmu Hukum

FAKULTAS HUKUM UMSU
Pendidikan Anti Kekerasan...(Nursariani, Rachmad Abduh)

Volume 5 Nomor 1, Januari - Juni 2020, 1-9

DOI: https://doi.org/10.30596/dll.v5i1.3290

1. Masyarakat belum memahami sepenuhnya tentang perilaku kekerasan pada anak serta dampaknya.

2. Masyarakat belum memahami sepenuhnya tentang pentingnya melakukan upaya pencegahan perilaku kekerasan pada anak.

3. Kurangnya kemampuan masyarakat dalam memecahkan masalah yang berkaitan dengan pencegahan perilaku kekerasan pada anak.

\section{METODE PENELITIAN}

Sesuai dengan permasalahan yang diteliti, penelitian ini merupakan penelitian hukum (legal research). Istanto, mengatakan penelitian hukum adalah penelitian yang diterapkan atau diberlakukan khusus pada ilmu hukum (Istanto, 2007, h. 29). Sejalan dengan Istanto, Marzuki mengatakan penelitian hukum adalah suatu proses untuk menemukan aturan hukum, prinsip-prinsip hukum, maupun doktrin-doktrin hukum guna menjawab isu-isu hukum yang dihadapi (Marzuki, 2005, h. 35).

Jenis penelitian yang digunakan dalam penulisan ini adalah penelitian pustaka (library research). Library research berarti penelitian yang menggunakan dokumen tertulis sebagai data, dan sumber data yang digunakan dalam penelitian ini mencakup bahan hukum primer, bahan hukum sekunder dan bahan tersier. Bahan hukum primer adalah bahan hukum yang mengikat atau yang membuat orang taat hukum, meliputi produk hukum yang menjadi bahan kajian dan produk hukum sebagai alat kritiknya. Bahan hukum sekunder meliputi penjelasan bahan hukum primer berupa doktrin para ahli yang ditemukan dalam buku, jurnal, dan dalam website, dan wawancara dan studi lapangan dijadikan sebagai data tamabahan.

\section{PEMBAHASAN DAN ANALISIS}

Pelaksanaan kegiatan Pengabdian kepada Masyarakat dilaksanakan pada Ikatan Komunitas Pemuda Tanah 600 Medan Marelan, Medan dan Karang Taruna Karya Buana Medan. Dalam kegiatan tersebut dilakukan ceramah, dialog, diskusi, dan pelatihan pemecahan masalah yang terkait dengan peningkatan kesadaran hukum terhadap pemberantasan kekerasan yakni mengenai pencegahan perilaku kekerasan pada anak. Untuk menyukseskan penyelenggaraan program tidak terlepas dengan prosedur birokrasi yang dilakukan oleh tim pelaksana dari UMSU. Proses administrasi yang dilakukan tim pelaksana program adalah koordinasi dengan LPPM UMSU untuk meminta surat pengantar kegiatan pengabdian yang substansinya memuat Permohonan untuk Mengadakan Pengabdian Pada Masyarakat dengan tema: PKM pendidikan anti kekerasan bagi masyarakat guna pencegahan perilaku kekerasan pada anak.

Kegiatan PKM ini diatur melalui langkah-langkah sebagai berikut ;

1. Koordinasi antara Tim pelaksana dengan mitra

2. Menyiapkan materi PKM

3. Menyiapkan narasumber yang memiliki kompetensi sesuai dengan target dan tujuan

4. Menyiapkan jadwal kegiatan Melakukan pengabdian kepada masyarakat, ceramah, dialog, diskusi, dan pelatihan pemecahan masalah (kasus kekerasan terhadap anak).

5. Evaluasi. 
DE LEGA LATA

Jurnal Ilmu Hukum

FAKULTAS HUKUM UMSU
Pendidikan Anti Kekerasan...(Nursariani, Rachmad Abduh)

Volume 5 Nomor 1, Januari - Juni 2020, 1-9

DOI: https://doi.org/10.30596/dll.v5i1.3290

Kegiatan koordinasi dan sosialisasi program PKM bagi Ikatan Komunitas Pemuda Tanah 600 Medan Marelan, Medan dan Karang Taruna Karya Buana Medan ditanggapi positif. Dengan adanya tanggapan positif tersebut kegiatan PKM bisa berjalan lancar, sehingga program dapat berjalan sesuai dengan waktu yang telah ditetapkan.

Pada pelaksanaan kegiatan, masyarakat sangat antusias mengikutinya. Kegiatan diawali dengan pemberian materi dalam bentuk ceramah dari narasumber. Narasumber lebih menekankan kepada masyarakat bahwa pencegahan kekerasan terhadap anak sangat penting dilakukan agar anak dapat tumbuh dengan sebaik-baiknya menjadi generasi penerus bangsa. Setelah itu dilanjutkan dengan diskusi.

Ada beberapa pertanyaan yang diajukan oleh anggota masyarakat pada saat kegiatan pengabdian kepada masyarakat dilakukan, yaitu:

1. Apakah yang dimaksud dengan kekerasan?

2. Apakah yang dimaksud dengan kekerasan fisik?

3. Apakah yang dimaksud dengan kekerasan psikis?

4. Apakah yang dimaksud dengan kekerasan seksual?

5. Apakah beda antara kekerasan fisik dengan keekrasan psikis?

6. Apakah akibat dari kekerasan?

7. Mengapa kekerasan yang dilakukan terhadap anak dapat menimbulkan peniruan?

8. Apakah anak yang sering dipukul dapat tumbuh menjadi seorang penjahat?

9. Apakah orang tua yang sering memukul anaknya dapat dihukum?

10. Apakah orang tua yang suka memukul anaknya dapat kita laporkan ke kantor polisi?

11. Bagaimana dengan seorang guru yang memukul anak muridnya? Apakah guru tersebut dapat dihukum?

12. Apakah hukuman bagi seseorang yang memukul anak?

13. Bagaimana cara kita sebagai orang tua untuk menanamkan nilai-nilai positif dalam kehidupan sehari-hari?

14. Bagaimana cara kita menahan emosi?

15. Apakah memaki atau mengejek seorang anak termasuk sebagai kejahatan?

16. Apakah yang harus kita lakukan agar tidak terjerumus kepada perbuatan kekerasan terhadap anak?

17. Bagaimana cara mendidik anak yang baik, agar mereka tidak menjadi anak nakal?

18. Bagaimana cara kita menyampaikan kepada tetangga yang sering memukul dan memaki anaknya dengan kalimat yang sangat kasar?

19. Bagaimana cara mengenali anak yang suka melakukan kekerasan?

20. Bagaimana cara menangani anak yang sering melakukan kekerasan?

21. Apakah ada kaitan antara kekerasan dengan tayangan kekerasan yang ada di sinetron televisi?

22. Apakah yang dapat dilakukan agar anak-anak kita tumbuh menjadi generasi penerus bangsa yang tidak mengedepankan kekerasan?

23. Bagaimana cara mengurangi agar anak tidak suka melakukan kekerasan pada temannya? 
DE LEGA LATA

Jurnal Ilmu Hukum

FAKULTAS HUKUM UMSU

Seluruh pertanyaan yang diajukan oleh anggota masyarakat, ditanggapi oleh narasumber. Setelah mendapat tanggapan, masyarakat mengetahui tentang hal-hal yang ditanyakannya. Kegiatan selanjutnya dilakukan pelatihan pemecahan masalah yang terkait dengan peningkatan kesadaran hukum terhadap upaya pencegahan kekerasan terhadap anak. Dalam kegiatan itu, masyarakat diberikan contoh kasus yang berkaitan dengan kekerasan yang pernah terjadi di dalam masyarakat. Berdasarkan contoh tersebut, kepada masyarakat dimintakan untuk dapat memecahkannya. Lalu diadakan dialog, dan beberapa anggota masyarakat memberikan tanggapannya.

Setelah itu, Tim Program Pelaksana memberikan pelatihan tentang tata cara pemecahan masalah jika terdapat kekerasan terhadap anak dalam masyarakat, serta cara-cara pencegahan kekerasan terhadap anak. Evaluasi kegiatan program PKM diarahkan kepada tiga aspek kinerja yakni; aspek perencanaan, aspek pelaksanaan dan aspek hasil. Untuk memudahkan kegiatan evaluasi ketiga aspek kinerja tersebut indikator keberhasilannya dijabarkan pada matrik berikut:

Matrik Evaluasi Kinerja Program PKM

\begin{tabular}{|c|c|c|c|c|}
\hline No & $\begin{array}{c}\text { Aspek Yang } \\
\text { Dievaluasi }\end{array}$ & $\begin{array}{c}\text { Indikator } \\
\text { Keberhasilan }\end{array}$ & Tolok Ukur & $\begin{array}{l}\text { Hasil yang } \\
\text { Diperoleh }\end{array}$ \\
\hline 1 & $\begin{array}{l}\text { Perencanaan/ } \\
\text { persiapan } \\
\text { kegiatan }\end{array}$ & $\begin{array}{l}\text { Tim PKM } \\
\text { membuat } \\
\text { program kerja } \\
\text { dan menyiapkan } \\
\text { bahan untuk } \\
\text { pelaksanaan } \\
\text { kegiatan }\end{array}$ & $\begin{array}{l}\text { Tersedianya } \\
\text { program kerja } \\
\text { secara detail dan } \\
\text { aplikatif. } \\
\text { Tersedianya bahan } \\
\text { untuk pelaksanaan } \\
\text { kegiatan }\end{array}$ & $\begin{array}{l}\text { Program kerja sudah } \\
\text { tersedia dan aplikatif. } \\
\text { Bahan untuk pelaksanaan } \\
\text { kegiatan (makalah, } \\
\text { kasus) sudah tersedia } \\
\text { dengan baik }\end{array}$ \\
\hline 2 & $\begin{array}{l}\text { Pelaksanaan } \\
\text { program } \\
\text { kegiatan }\end{array}$ & $\begin{array}{l}\text { Tim program } \\
\text { PKM menjalin } \\
\text { kerjasama untuk } \\
\text { dilakukan } \\
\text { pengabdian } \\
\text { kepada } \\
\text { masyarakat, dan } \\
\text { pelatihan } \\
\text { pemecahan } \\
\text { kasus }\end{array}$ & $\begin{array}{l}\text { Terlaksananya } \\
\text { kerjasama dan } \\
\text { kegiatan pengabdian } \\
\text { kepada masyarakat. }\end{array}$ & $\begin{array}{l}\text { Kerjasama dan kegiatan } \\
\text { pengabdian kepada } \\
\text { masyarakat } \\
\text { berjalan } \\
\text { sesuai jadwal } \\
\text { kegiatan. } \\
\text { Pelatihan pemecahan } \\
\text { kasus terlaksana dengan } \\
\text { baik. }\end{array}$ \\
\hline 3 & $\begin{array}{l}\text { Hasil } \\
\text { kegiatan }\end{array}$ & $\begin{array}{l}\text { Peserta } \\
\text { pengabdian } \\
\text { kepada } \\
\text { masyarakat } \\
\text { dapat: } \\
\text { a. Memahami } \\
\text { tentang } \\
\text { pentingnya } \\
\text { pencegahan } \\
\text { perilaku } \\
\text { kekerasan } \\
\text { pada anak. } \\
\text { b. Memahami }\end{array}$ & $\begin{array}{l}\text { Terlaksananya } \\
\text { peningkatan } \\
\text { pemahaman } \\
\text { masyarakat akan } \\
\text { pentingnya } \\
\text { pencegahan perilaku } \\
\text { kekerasan pada anak } \\
\text { serta mampu } \\
\text { memecahkan masalah } \\
\text { terkait perilaku } \\
\text { kekerasan pada anak. }\end{array}$ & $\begin{array}{l}\text { Peserta pengabdian } \\
\text { kepada masyarakat } \\
\text { mampu: } \\
\text { a. Memahami tentang } \\
\text { pentingnya } \\
\text { pencegahan perilaku } \\
\text { kekerasan pada anak. } \\
\text { b. Memahami tentang } \\
\text { cara pencegahan } \\
\text { perilaku kekerasan } \\
\text { pada anak. } \\
\text { c. Memiliki kemampuan } \\
\text { dalam memecahkan }\end{array}$ \\
\hline
\end{tabular}




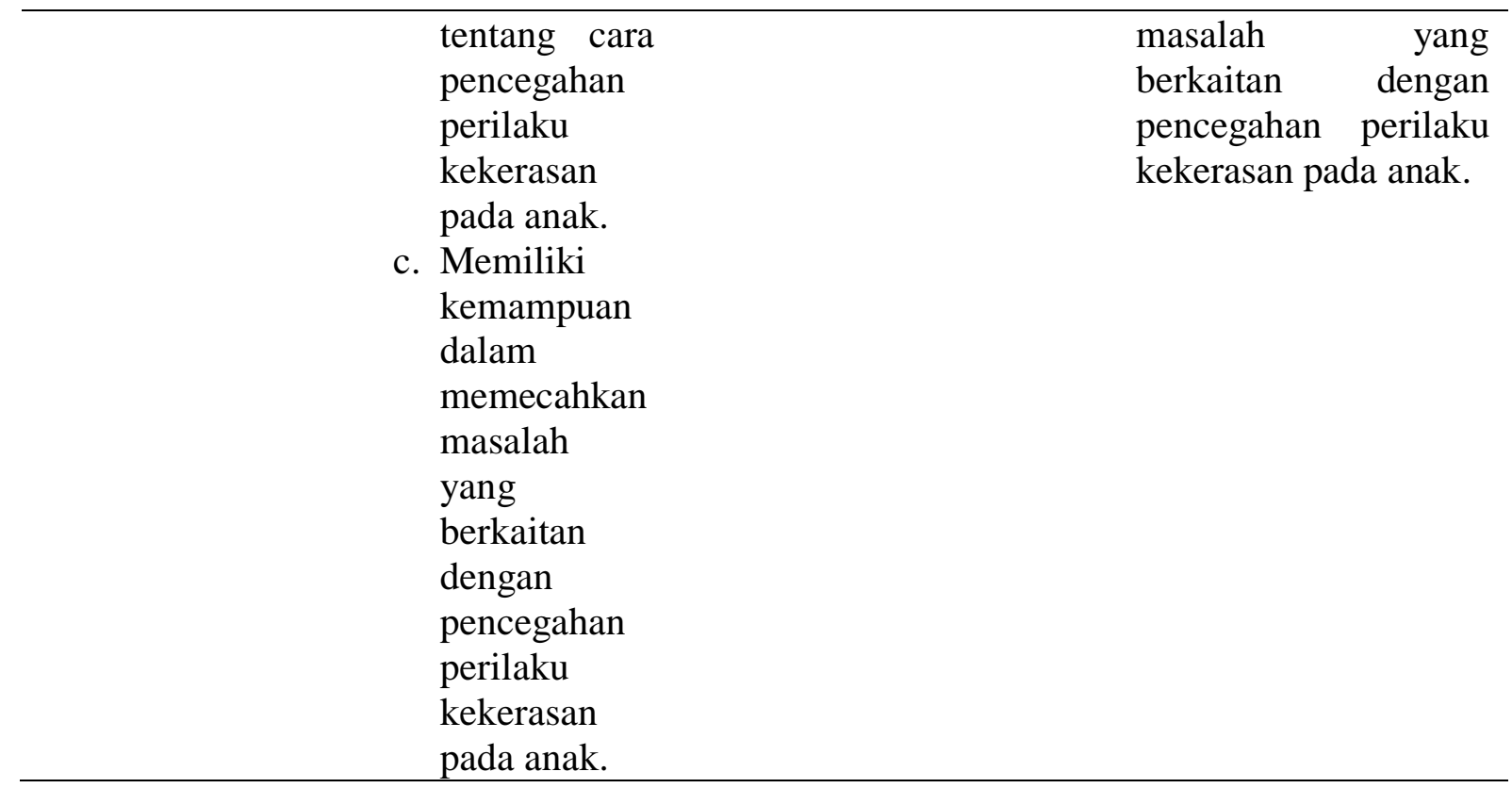

Selama pelaksanaan program PKM tidak ditemukan permasalahan atau hambatan. Hal ini mengakibatkan pelaksanaan program PKM berjalan dengan lancar serta sesuai dengan yang diharapkan.

\section{KESIMPULAN}

Berdasarkan data hasil monitoring dan evaluasi yang telah dilakukan oleh Tim pelaksana terhadap program PKM dapat diambil beberapa kesimpulan diantaranya, yaitu; bahwa program PKM sangat bermanfaat bagi warga masyarakat, dimana program PKM yang telah dilaksanakan bisa berjalan dengan baik tanpa ada hambatan yang berarti terlihat masyarakat sangat antusias mengikuti kegiatan yang dilaksanakan dan masyarakat dapat melakukan pemecahan masalah jika terjadi perilaku kekerasan pada anak.

\section{SARAN}

Saran berkait dengan pelaksanaan program PKM ini, kami sampaikan sebagai berikut; pertama, warga masyarakat (anggota persatuan) hendaknya selalu bisa melakukan pencegahan perilaku kekerasan pada anak dan kedua, ketua persatuan hendaknya selalu memberikan motivasi kepada warga masyarakat khususnya para anggota yang telah mengikuti kegiatan dan pelatihan, untuk senantiasa dapat memanfaatkan pengetahuan dan keterampilan yang telah diterima selama mengikuti penyuluhan dan pelatihan. 
Jurnal Ilmu Hukum

FAKULTAS HUKUM UMSU
Pendidikan Anti Kekerasan...(Nursariani, Rachmad Abduh) Volume 5 Nomor 1, Januari - Juni 2020, 1-9 DOI: https://doi.org/10.30596/dll.v5i1.3290

\section{DAFTAR PUSTAKA}

Asmadi, Erwin. (2018). Peran Psikiater Dalam Pembuktian Kekerasan Psikis Pada Korban Tindak Pidana Kekerasan Dalam Rumah Tangga. Jurnal De Lega Lata, 3(1), 39-51. https://doi.org/10.30596/dll.v3i1.3136

Hadjam, M. Noor Rochman., Wahyu Widiarso. (2003). Budaya Damai Anti Kekerasan (Peace and Anti Violence). Jakarta: Dirjen Pendidikan Menengah Umum

Huraerah, Abu. (2012). Kekerasan Terhadap Anak. Bandung: Nuansa Cendekia

Fajaruddin. (2018). Efektivitas Undang-Undang Nomor 33 Tahun 2014 Tentang Jaminan Produk Halal Dalam Perlindungan Konsumen, 3, (2), 204-216. https://doi.org/10.30596/dll.v3i2.3151.

Istanto, F.S. (2007). Penelitian Hukum. Yogyakarta: CV. Ganda

Marzuki, P.M.. (2005). Penelitian Hukum. Jakarta: Kencana Prenada Media Group

Nashriana. (2012). Perlindungan Hukum Pidana bagi Anak di Indonesia. Jakarta: Rajawali Pers

Undang-Undang Nomor 35 Tahun 2014 tentang Perubahan atas Undang-Undang Nomor 23 Tahun 2002 tentang Perlindungan Anak

Undang-Undang Nomor 17 tahun 2016 tentang Perubahan Kedua atas Undang-Undang Nomor 23 Tahun 2002 tentang Perlindungan Anak

Undang-Undang Nomor 23 Tahun 2002 tentang Perlindungan Anak 